\title{
On the Necessity of the CPC's Construction in Soft Power
}

\author{
Yuzhi Zhang \& Ying Li \\ School of politics, Qufu Normal University Rizhao Campus \\ Rizhao 276826, China \\ E-mail: zyz911@yeah.net
}

\begin{abstract}
The theory of Soft power can be applied to the ruling party of social governance. At present, the Chinese Communist Party is facing political corruption, the public lack of political trust in the officials, social injustice and other social issues. It is necessary to construct the party's soft power and consolidate the party's ruling position.
\end{abstract}

Keywords: Soft power, The Chinese Community Party, Domestic governance, Theory Z

\section{The Soft Power Theory and Domestic Governance}

Soft power theory was first put forward by Joseph Nye, the U.S. famous scholar of international relations in 1990s. It is mainly used in international politics and international relations. The power is divided into two kinds from the development perspective. One is hard power, the other is soft power. Joseph Nye argued that," soft power was through attraction rather than coercion to achieve the wish. It originated from a country's culture, political ideas and foreign policies." (Joseph Nye, 2005, p.2) In international politics, a country affected other country's conduct to achieve its objectives in a variety of ways. It let other countries yield by the means of violence. It can use the economic benefits to entice other countries and let them acknowledge its goal. You can also use ideology, culture and political values and other factors to attract other countries to achieve the voluntary target, while the latter belongs to soft power. Compared in terms of hard power, soft power is the power of another form of expression and a non-material power. That is a kind of recognition or assimilation of power. In essence, the soft power is manifested in the cultural, political values and policies. (Joseph Nye, 1990, pp.165-168) The greatest feature is the use of attraction rather than coercion. The political actors achieve its goals in the subtle way rather than the frenetic method.

In accordance with Nye's theory of power, the power can be divided into hard power and soft power these two different types. The theory of soft power is used in the domestic politics of governance. Soft power is an act of power, which is manifested by the ruling party's political values, social and governance model, and domestic and foreign policies, etc., in order to achieve the purpose of harmonious society, so it has a constructive and cooperative characteristic. Compared with the soft power, hard power behavior is well known, which is a power of resource, material power, or coercive power, so it comes mainly from military and economic power, which is brought about by the violence and wealth. The country uses state organs and its legal systems to control other countries and other people, and drive them submit to its will. All kinds of modern society, experience has shown that the cost of the use of hard power is often very high, and the results may not be very satisfactory. During the domestic political governance process, of course, hard power can not be ignored, but the excessive use of hard power will damage the ruling party's governing capacity and administrative effectiveness especially in modern society in which science and technology and information develop well. If the ruling party governs the community only by virtue of or over-reliance on hard power, it would not unite the people and effect social stability. It most likely damages the ruling party's political authority, so that make the whole society into anomie, disorder, or even into a split. Therefore, the society in different development stages should use different form of power.

At present, Joseph Nye's theory of soft power is widespread concerned in the domestic various academic fields, such as political science, management, administrative science, economics, cultural studies and many other scholars. The theory is introduced to the areas of expertise, combined with the relevant content of the professional research, and has made some research and put forward new ideas. On the theory of soft power and domestic political governance research, some researchers have been involved in. Some scholars argues that soft power has different levels, which is divided into human level, level of domestic politics and international political level; (Gong,2008,pp.115-132) and some scholar thinks that the theory of soft power also applies to a country's internal social governance. (Li, 2008, pp.18-20) However, to sum up, research in this field remains to be further deepened. In view of this, the author based on the analysis of Joseph Nye's soft power theory; attempt to apply this new method to analyze the concrete realities of China's politics. The author put forward the view 
that the ruling party of Chinese society -- CPC needs to strengthen soft power in the process of governance in order to construct the harmonious society.

With the above theory of soft power also echoes the $\mathrm{z}$ theory that William G.Ouchi proposed. Theory $\mathrm{Z}$ bases on McGregor's theory X and theory Y, which emphasizes the cultural factors about organization and management. We should consider organizing the soft factors in the management, such as trust, interpersonal relations and the delicate nature and so on. Theory $\mathrm{Z}$ emphasizes the human factor in the organization and management in the East. These proposals are consistent with the soft power theory, and issues of mutual interest are common. $\mathrm{Z}$ theory embodies the characteristics of the management of the East; China's domestic governance must also follow the principles of the theory Z. Communist Party of China need to build soft power, using this theory to govern the country, which embodies the philosophy of the theory $\mathrm{Z}$.

\section{The Necessity to Build the CPC's Soft Power in the Process of the Domestic Governance}

There is a marked change in the way of contemporary international competition, which is shifted from the traditional hard power to soft power competition among nations. Therefore, a country enhances its soft power capabilities in order to have international competition. It requires the ruling party to strengthen the building of soft power in the governance of domestic politics. The ruling party should improve its overall competitiveness. Hard power is the country's competitive core in the agricultural and industrial society, while soft power is the country's competitive core or the main elements of the national competition in modern science and technology, information-oriented society. As everyone knows, before the end of the Cold War, state's power mainly comes from land, resources, population, industrial and military strength. These all are hard power. During the Cold War, competition among nations is the hard power of competition. A country often vigorously developed military force and expanded its resources in order to enhance its competitiveness. After the Cold War, the international society is becoming more knowledge-oriented and information-oriented. Military force and resources-based hard power competition is no longer a core element in international competition. Political ideology and culture-based soft power is the focus of competition in international competition. The soft power of competition would be a gradual increase in the proportion and it has become an important way to the contemporary power of competition. In this mode of competition, the power is becoming more diffuse, more intangible, and its use is becoming increasingly lack of force. The power of the traditional framework gradually digests. The new framework of power with modern features is gradually constructed. With the change of times and society, it demands the ruling party's governance philosophy changing from mainly relying on hard power into relying on soft power, so the ruling party should shift the governance paradigm.

China wants to enhance own international competitiveness in this international context. We must strengthen the country's soft power. If China wants to enhance the domestic soft power, it is necessary to improve the soft power of the Chinese Communist Party in the domestic politics of governance. Therefore, the upgrading and construction of the ruling party's soft power is the key to solve this problem. Overview of contemporary Chinese society, the Chinese Communist Party wants to enhance the soft power. It still faces many pressing problems, such as the corruption of political power, economic division between the rich and the poor, the people lack of the identity with the ruling party's ideological and political values, etc., These problems have greatly damage and weaken the ruling party's soft power. We should resolve these problems in order to fundamentally improve the soft power of the Communist Party of China, which greatly strengthen the Chinese Communist Party's ruling capacity and administrative levels.

First, the political corrupt problem is an important issue which is urgent to solve for building the soft power of the ruling party. The political corrupt problem not only seriously damages the party's resources, weakening the party in the implementation of political governance, but also completely destroys the ruling party's ability to govern, which the ruling party must face up to the serious political problem. The Party Congress report pointed out: "we do not crack down on corruption. The party's ties with the masses would be seriously damaged. The party's ruling position is in danger. The party is likely to move toward self-destruction. " (Jiang, 2002) The problem of corruption in domestic politics has increasingly become a prominent issue since the reform and opening. In 2009 alone, there are nearly more than 20 provincial-level officials amid the national anti-corruption falling, such as Xu Zongheng, the original Mayor of the Shenzhen Municipal Committee, assistant Zheng Shaodong, the Ministry of Public Security of the original party members, Wang Huayuan, Zhejiang Province Commission for Discipline Inspection, Chen Shaoji, former chairman of Guangdong provincial political consultative conference, Pi Qiansheng, Tianjin Municipal Standing Committee etc.. The high frequency of the falling of high-ranking officials is very rare. We overall look the whole political group. The number of involving public corruption, the high level, the huge amount, the magnitude are beyond of the before "record." Officials below the provincial department and provincial department-level corruption are even more startling. These 
results clearly indicate that the current political power corruption is very serious harm to the ruling party's image, weakening the ruling party's soft power.

Corruption makes the ruling party loss of political power indeed, which is already proved by the experience of the foreign party. For instance, the Soviet Union and Eastern Europe, and changes in these countries have a direct relationship with the Communist Party of corruption. There were the "color revolutions" in Georgia, Ukraine, and Kyrgyzstan because these countries had rampant corruption in recent years. Japan's Liberal Democratic Party, Mexico's Institutional Revolutionary Party, the Indonesian Golkar (Functional Group politics), the Indian National Congress and other major party and the old political parties, which were in power more than three decades. They stepped down for different reasons, but had one thing in common, namely, the serious corrupt problem. These ruling party abused state power for money, economic scandals, resulting in the loss of their own people's support, leading to the ruling foundation shaken, eventually lost its ruling position. From this we can clearly recognize that the problem of corruption is an important factor for the ruling party loss of soft power. The Chinese Communist Party should adopt the blood historical lessons of the above ruling party in particular, which deserves careful consideration and learn the lessons of their failure, thus firmly determine to tackle corruption, so that the ruling party maintains a good political image and enhances the soft power of governance and improves people's social cohesion.

Secondly, in the process of social development, with the class of continuous differentiation, appearing more and more social injustice, particularly in economic polarization between the rich and the poor is most prominent. The soft power of the ruling Communist Party of China has been continued weakening at present. After reform and opening, through 30 years of development, China's economic level has been greatly improved, the total ranks third in the world. China's political status in the international community improved significantly. However, China's economic reform leads to the most important issue which is the issue of social justice. The issues include the distribution of income inequality, regional imbalance, urban-rural inequality, the gap between sectors of education, unfair in the health care and other aspects of employment. In many problems, the people feel that the growing polarization between the rich and the poor is the deepest and most strongly reflected issue. In accordance with internationally accepted the differences in residents' income distribution - the Gini coefficient, according to the data released by the World Bank show that China's Gini coefficient of income has been developed from the beginning of the reform and opening 0.23 to 0.48 in 2007 , more than the international warning level 0.4. The data was more serious than all the world's developed countries. The widening gap between the rich and the poor has become an indisputable fact in the Chinese society. The Boston Consulting Group released the "2006 World Wealth Report" also shows that China's 1.5 million households (about $0.4 \%$ of the total number of households) occupies $70 \%$ of China's total wealth, while in Japan, Australia and other developed countries, generally $5 \%$ of households control $50 \%$ of the national wealth. China has become the world's highest concentration of wealth countries; the Gini coefficient of China ranked first in 22 Asian countries. The widening gap between the rich and the poor is the focus in the China economical development. The ruling party must face and trickle the key problem.

While the gap between the rich and the poor is too small, which will make society lack of competitive vitality, leading to the slow development. But the gap between the rich and the poor was too big, which would result in more acute internal contradictions of society. It is a serious threat for the ruling party. Aristotle, the fourth century BC Greek philosopher had long been aware of this, he said: "If a regime in the absence of the middle class, the poor accounted for an absolute advantage in numbers, then the civil strife would soon occur, then the city-states were attributed to disintegration." (Aristotle, 2003, pp.139-140) In the same country, a minority of persons were too rich, while the most people in destitute and social unrest growing. The serious problem threatens the legitimacy of the ruling party and the ruling stability to the extent. Some of the negative impact caused by the gap between the rich and the poor is increasingly prominent among China's current problems, leading to all kinds of social instability, seriously weakened the ruling party's soft power and ability to govern.

Thirdly, there is lack of trust between the ruling political ideology and ordinary people. The power corruption and the gap between the rich and the poor lead to the serious consequences. The corruption of the ruling party undermined the influence of mainstream ideology. The ruling party was generally questioned by the people because of the society's ever-widening gap between the rich and the poor, resulting in people's trust in the ruling party increasingly low, so that appears governmental signs of a crisis of confidence.

Judging from the current view of the ruling party's governing philosophy, there is also some party officials still sticking to the traditional ruling political philosophy in the process of social governance. Such as the fundamental issues, e.g. where the power is from and who they service, and so on, some part officials do not recognize clearly. Thus, such situations often occur in the process of governing: only worshipped and dedicated 
to superior, not for the people, not looking the people's interests as the starting point and ending point. In the survey, 64\% of people think that their power depends on the leadership's approval, "power is given by the leadership"; $30 \%$ of people think that the leadership and personal efforts account for each half; $5 \%$ of the people rely on individual efforts; only $1 \%$ of people think that the power is given by the masses. (Lu, 2002, p.266)On the basis of this political values, their performance appeared serious deviations. It is the main concern for them to gain performance in order to facilitate their official promotion .It is not their responsibility to solve the people's problems. And even some corrupt officials privately use the public power, regarding themselves as the rulers of the society and the people. In the processes of social management, they used hard power to compete with the people for interests and seriously damaged the fundamental interests of the people, leading to the public distrust of the ruling party, weakening the ruling party's political soft power, thereby undermining the legitimacy of the ruling party, which is not in line with the development trend of modern political civilization.

Be different from the traditional rule-oriented government, the modern public is more inclined to agree with the ruling party's service-oriented political governance. They look the corrupt officials as economic exploiters and political oppressors. The public had serious differences from the corrupt officials adhering to the traditional ruling political ideas. At present, our society is not yet a people-based society, but official society or the power-based society. In the current world trend, the "small government and big society" democratic model have great development. China's "big government small society" power structure is making the people general lack of social security. The people and the ruling party's interest are one social community. The ruling party should protect the public interests firstly, but because of some reasons, the both sides' interests show increasing polarization tendency. The political confidence crisis seriously weakened the ruling party's soft power, so that our party's social identity greatly reduced. In the twenty-first century information society, in order to consolidate the ruling party's political status, heavily relying on hard power and the traditional governance model, this is not only undesirable but also impossible. Therefore, the ruling party needs to intensify soft power in order to better govern our society.

\section{Conclusions}

Joseph Nye put forward the theory of soft power. His fundamental starting point services for American foreign policy in order to safeguard U.S. national interests. Chinese scholars should pay special attention to it in the learning theory of soft power especially in academic research. However, the theory of soft power does reveal the objective development path of power. It meets the development of the times. We think that the ruling party may use the theory in the domestic political governance. We should build a harmonious society, which is our political ideal. We can draw on the theory of soft power during constructing the harmonious society.

In addition, the Chinese Communist Party's domestic management should learn from the international advanced theories, such as the Marc Holzer's performance management theory, David Osborne's entrepreneurial government theory and Robert B. Denhardt's new public service theory and so on. Personnel Management will be based on the $\mathrm{Z}$ theory, rather than established on the basis of X-theory now. In short, the ruling party's internal governance is essential for the consolidation of its political status. Soft power building will help the ruling party effectively improve the management level, in order to let our society gradually toward harmonious.

\section{References}

Aristotle. (2003). Political science. Yan, Yi and Qin, Dianhua translated. Beijing: Chinese People University Press.pp.139-140.

Department of Culture of Shandong Province. The subject of "soft power and harmonious society." the medium-term results. Project number: 20080083.

Gong, Tieying. (2008). The systematic analysis of soft power. Tianjin: Tianjin People's Publishing House.pp.115-132.

Jiang, Zemin. (2002). Comprehensively building a moderately prosperous society and create a new situation in the socialist cause with Chinese characteristics - the Chinese Communist Party's Sixteenth National Congress of the report. China News Net, [Online] Available: http://www.chinanews.com.cn / 2002-11-17/26/244524.html (Oct.10, 2009)

Joseph Nye. (1990). Soft Power. Foreign Policy. Fall (80).pp.165-168.

Joseph Nye. (2005). Soft power - the means to success in world politics. Wu ,Xiaohui and Qian, Cheng translated. Beijing: Oriental Press.p2.

Li, Liaoning. (2008). On the social harmony and the building of the ruling party's soft power. The only real, (4).pp.18-20.

LU, Xianfu. (2002). Construction of China's ruling party. Shanghai: Shanghai People's Publishing House.p266. 